\title{
Development and validation of a microbial counting method for mebendazole oral suspension
}

\author{
Polyana Araújo de Assis ${ }^{1}$, Severino Borba de Andrade², Clécia Maria Carvalho de Oliveira², \\ Patrícia Menezes de Araújoº ${ }^{2}$, Severino Grangeiro Júnior ${ }^{3}$, Selma Verônica Vieira Ramos, ${ }^{4, *}$
}

\author{
${ }^{1}$ Department of Pharmacy, University of Brasilia, ${ }^{2}$ Laboratory of Immunohematology, Clinical Hospital, Federal University \\ of Pernambuco, ${ }^{3}$ Department of Pharmacy, Federal University of Pernambuco, ${ }^{4}$ Pharmaceutical Laboratory of Pernambuco \\ State Governor Miguel Arraes, LAFEPE
}

\begin{abstract}
Mebendazole is an important medicine used to treat helminth infections. These infections affect more than two billion people worldwide. The LAFEPE ${ }^{\circledR}$ (Recife-PE, Brazil) produces the drug mebendazole oral suspension that contains the preservatives methylparaben and propylparaben in its formulation. Drugs that have antimicrobial properties due to preservatives must undergo neutralization of these compounds to allow microbial count testing according to recommendations by the official compendia. In order to obtain a validated method for microbial counting and to ensure its safety and reliability within the pharmaceutical industry, validation of preservative neutralization and of the method for microbial counting was performed according to the USP 30 and PDA Technical Report No. 33. The method used ATCC Gram positive and Gram negative microorganisms, yeasts, most and culture media Tryptic Soy Agar and Sabouraud dextrose agar. The neutralizers were polysorbate 80 and lecithin. Recovery levels of over $70 \%$ of the microorganisms used in the test indicated the neutralization of antimicrobial activity and proved the absence of toxicity of neutralizers. The microbial counting method validated proved accurate, precise, robust and linear and can be safely used in routine operations.
\end{abstract}

Uniterms: Mebendazole/oral suspension. Microbial count.

O mebendazol é um importante medicamento utilizado no tratamento de infecções por helmintos. Essas infecções afetam mais de dois bilhões de pessoas em todo o mundo. O LAFEPE (Recife-PE, Brasil) produz o medicamento mebendazol suspensão oral, que possui em sua formulação os conservantes metilparabeno e propilparabeno. Em medicamentos que possuem propriedades antimicrobianas em decorrência dos conservantes faz-se necessária a neutralização da ação desses compostos para a realização do teste de contagem microbiana segundo preconizado pelos compêndios oficiais. A fim de obter um método de contagem microbiana validado e que garanta sua segurança e reprodutibilidade dentro da indústria farmacêutica foi realizada a validação da neutralização dos antimicrobianos e validação do método de contagem microbiana de acordo com a USP 30 e PDA-Technical Report №33. O método desenvolvido utilizou microrganismos ATCC Gram positivos, Gram negativos, leveduras e fungos e meios de cultura Tryptic Soy Agar e Sabouraud-dextrose Agar. Os neutralizantes foram polissorbato 80 e lecitina de soja . Níveis de recuperação superiores a 70\% dos microrganismos utilizados no ensaio indicaram neutralização da atividade antimicrobiana e comprovou a ausência de toxicidade dos neutralizantes. O método de contagem microbiana validado revelou-se exato, preciso, robusto e linear podendo ser utilizado com segurança na rotina operacional.

Unitermos: Mebendazol/suspensão oral. Contagem microbiana.

*Correspondence: S.V.V. Ramos. Laboratório Farmacêutico do Estado de Pernambuco Governador Miguel Arraes. Largo de Dois Irmãos 1117 - Dois Irmãos - 52171-010 - Recife - PE, Brasil. E-mail: selma.vieira@lafepe.pe.gov.br 


\section{INTRODUCTION}

Scientific and technological advances in recent decades have enabled better development and control of drugs, universally determining the minimum efficacy, safety and quality requirements of medicines (Carvalho et al., 2004; Bomblies, Weiss, Beckmann, 2007). Drug quality is related to the degree of compliance with such requirements and minimum standards determined by official standards. To ensure these requirements are met it is necessary to perform physical, chemical and biological tests (Itah, Udokpoh, Ofum, 2004).

In order to ensure the microbiological quality of mebendazole oral suspension $20 \mathrm{mg} / \mathrm{mL}$, microbiological tests should be performed, among them the microbial counting test advocated by both the Brazilian Pharmacopoeia IV edition and the USP 30 (Bou-Chacra, 2003; F.Bras. IV, 1988; USP, 2007).

Methods of microbial counting seek to assess the total number of bacteria, yeasts and most using specific culture media. This method includes a series of validations, such as: neutralization of antimicrobial agents, recovery of test microorganisms and the microbial counting method itself. The USP 30 and PDA Technical Report No. 33 describe which key precision, accuracy, robustness and linearity parameters are to be observed in this validation. In addition, another important factor is that the method implemented is validated for each product analyzed (USP, 2007; Ramos, 2010).

In this study, mebendazole oral suspension $20 \mathrm{mg} /$ $\mathrm{mL}$ produced by the LAFEPE Laboratory (Pharmaceutical Laboratory of Pernambuco Governor Miguel Arraes S/A) was investigated. Mebendazole is one of most widely used anthelmintic drugs (Goodman and Gilman, 2006) and classified by the World Health Organization (WHO) as an essential medicine based on its clinical efficacy, low cost and ease of administration (Agatonovic-Küstrin et al., 2008). This drug belongs to the class of benzimidazole derivatives which includes albendazole and thiabendazole. It has a broad spectrum of activity, acting on cestodes and nematodes parasites. (Bennett, Guyatt, 2000).

Mebendazole oral suspension $20 \mathrm{mg} / \mathrm{mL}$ produced by the LAFEPE laboratory is a non-sterile product containing parabens preservatives in its formulation at the proportions of $0.06 \%$ propylparaben $(\mathrm{w} / \mathrm{v})$ and $0.16 \%$ methylparaben $(\mathrm{w} / \mathrm{v})$. The antimicrobial system used in the manufacturing of mebendazole oral suspension is important to ensure the stability and safety of the product with respect to microbiological purity, in addition to protecting the user from any health compromise due to product contamination. This is no substitute however, for the good manufacturing practices inherent in the ma- nufacturing process of pharmaceutical industries (Pinto, Kaneko, Ohara, 2003; Russell, 2003). The conducting of a validation test for antimicrobial agent neutralization and for microbial counting method validation thus become key factors that will prove the method's effectiveness in recovering product contaminants. This is necessary since the presence of preservatives may promote microbial growth inhibition, thereby preventing the determination of total number of colonies present in the sample. Furthermore, immune-compromised patients who make use of oral drugs may experience an aggravated clinical condition if these products are microbiologically contaminated. In addition to the objectives outlined is the review of the scarce scientific publications dealing with the subject and their application in pharmaceutical industries.

\section{MATERIAL AND METHODS}

\section{Substances and culture media}

To validate the microbial counting method, polysorbate 80 (Oxiteno ${ }^{\circledR}$ - Lot 16506$)$, soy lecithin (Inlab ${ }^{\circledR}$ - Lot 832490), sodium chloride solution, 0.9\% (Fresenius $\mathrm{Kabi}^{\circledR}$ - Lot 040702 059), Soybean casein broth (Difco ${ }^{\circledR}$ - Lot 8150627), casein soy agar (Difco ${ }^{\circledR}$ - Lot 9160882 , Merck $^{\circledR}$-Lot VM803358714 and Oxoid ${ }^{\circledR}$ - Lot 463341), Sabouraud dextrose agar (Difco ${ }^{\circledR}$ - Lot 6319541, Merck $^{\circledR}$ - Lot VM804238723 and Oxoid ${ }^{\circledR}$ - Lot 476969), and Sabouraud dextrose broth (Difco ${ }^{\circledR}$ - Lot 6269292, Merck $^{\circledR}$ - Lot VM462926 and Oxoid ${ }^{\circledR}$ - Lot 455812) were used.

The dosage form used was mebendazole (oral suspension $20 \mathrm{mg} / \mathrm{mL}$ - Lot 09120754) produced by the LAFEPE $^{\circledR}$ (Pharmaceutical Laboratory of Pernambuco Governor Miguel Arraes).

\section{Test microorganisms}

For microbiological tests, the microorganisms described in the official compendia F. Bras. IV and USP 30 (2007): Aspergillus niger ATCC 16404 (Cefar ${ }^{\circledR}$ - Lot CBC295), Candida albicans ATCC 10231 (Cefar ${ }^{\circledR}$ - Lot CBH360), Escherichia coli ATCC 8739 (Cefar ${ }^{\circledR}$ - Lot CBI370), Pseudomonas aeruginosa ATCC 9027 (Cefar ${ }^{\circledR}$ Lot CBE322), Staphylococcus aureus ATCC 6538 (Cefar ${ }^{\circledR}$ - Lot CBJ383) were employed.

\section{Preparation of microbial suspension and inoculum standardization}

From the stock cultures in casein soy agar, bacteria were transferred with the aid of a platinum loop calibrated 
at $10 \mu \mathrm{L}$ onto $5 \mathrm{~mL}$ soybean casein broth liquid medium. These cultures were incubated for $18-24$ hours at $32 \pm 2{ }^{\circ} \mathrm{C}$. Serial dilutions in $0.9 \%$ sodium chloride solution were carried out and the last three were plated and incubated for 24 hours at $32 \pm 2{ }^{\circ} \mathrm{C}$ and listed in order to obtain a standardized microbial suspension to $10^{2} \mathrm{CFU} / \mathrm{mL}$. For yeasts and most standardization, a similar methodology to that for bacteria was used, except for the media employed which were liquid and solid Sabouraud-dextrose. The transfer of Aspergillus niger culture was facilitated by suspending spores in $2 \mathrm{~mL} 0.9 \%$ sodium chloride solution added to $0.05 \%$ polysorbate 80 solution. These cultures were incubated at $22 \pm 2{ }^{\circ} \mathrm{C}$ for 48 hours or 96 hours for Candida albicans and Aspergillus niger, respectively.

\section{Validation of preservative neutralization}

Based on the drug formulation, chemical neutralization using $0.4 \%$ polysorbate $80\left(\right.$ Tween $\left.^{\circledR} 80\right)(\mathrm{w} / \mathrm{v})$ and $0.5 \%$ soy lecithin (w/v) was chosen, as recommended by the official compendia (F. Bras. IV, 1988; USP, 2007) and $1: 10$ dilution $(\mathrm{v} / \mathrm{v})$ was used for the water soluble products.

Determining the efficacy and toxicity of the neutralizer is required to ensure the validation process of antimicrobial agent neutralization.

This is observed through microorganism recovery in different groups for analysis: test $(\mathrm{T})$, peptone $(\mathrm{P})$ and viability (V) (USP, 2007). The comparison between the test group and peptone group demonstrates neutralization effectiveness, whereas the comparison between the peptone group and viability group demonstrates neutralization safety i.e. that it has no toxicity.

These tests were performed in quintuplicate and the criterion used to demonstrate neutralization validation was as recommended by the 2007 USP, which determines the recovery of test microorganisms to be greater than or equal to $70 \%$.

\section{Preparation of analysis groups}

The test group $(\mathrm{T})$ and peptone $(\mathrm{P})$ are composed of $90 \mathrm{~mL}$ casein soy broth supplemented with $0.4 \%$ polysorbate $80(\mathrm{w} / \mathrm{v})$ and $0.4 \%$ soy lecithin $(\mathrm{w} / \mathrm{v})$, and $10 \mathrm{~mL}$ drug or $10 \mathrm{~mL} 0.9 \%$ sodium chloride, respectively. The viability group (V) comprises casein soy broth only $(100 \mathrm{~mL})$.

From the analysis groups, $1.0 \mathrm{~mL}$ aliquots were taken and deposited in sterile Petri dishes concomitantly with 0.3 or $1.0 \mathrm{~mL}$ of standardized suspension of test microorganisms. Subsequently, about $17 \pm 2 \mathrm{~mL}$ of solid soy casein or Sabouraud dextrose media was poured and the contents homogenized. Petri dishes remained on a flat surface until complete medium solidification. Subsequently, plates were incubated at $32 \pm 2{ }^{\circ} \mathrm{C}$ for 48 hours for bacteria and $22 \pm 2{ }^{\circ} \mathrm{C}$ for 48 hours or 96 hours for Candida albicans and Aspergillus niger, respectively. The reading was performed after this period by counting the colonies using a digital counter (Quimis ${ }^{\circledR}$ ) and the results expressed in colony forming units/plate.

\section{Development and validation of microbial counting method}

The microbial counting method was validated according to the parameters: precision, accuracy, linearity and robustness recommended by the USP-30 and PDA Technical Report No. 33.

Precision was evaluated at two levels: repeatability (intra-run precision, $\mathrm{n}=5$ ) and intermediate precision (inter-run precision, $\mathrm{n}=5$ per analyst). The repeatability and intermediate precision were evaluated in the three groups for analysis (test, peptone and viability) with two levels of microbial incrimination, one with a 10-30 CFU/plate and the other with a 30-300 CFU/plate.

The criterion used to prove the accuracy of the method at the level of repeatability was as recommended by USP 30, which determines a maximum variation coefficient of $25 \%$ or $15 \%$ when groups are incriminated with 10-30 CFU/plate or 30-300 CFU/plate, respectively. Data obtained for the intermediate precision were statistically analyzed by ANOVA (Neto, Scarmino, Bruns, 2001). The accuracy was assessed by comparing the values obtained for test microorganism recovery in the test $(\mathrm{T})$, peptone $(\mathrm{P})$ and viability $(\mathrm{V})$ groups. To achieve this, fixed volumes of $0.3 \mathrm{~mL}$ and $1.0 \mathrm{~mL}$ of microorganism suspension standardized in $10^{2} \mathrm{CFU} / \mathrm{mL}$ were used to frame the analysis groups, thus achieving incrimination levels of 10-30 CFU/ plate and 30 - $300 \mathrm{CFU} /$ plate.

The criterion used to prove the accuracy of the method recommended by USP 30 determines test microorganisms recovery of less than $70 \%$.

The linearity of the method was verified through the correlation among different volumes $(0.2,0.4,0.6,0.8,1.0$ and $1.2 \mathrm{~mL}$ ) which were taken from the analysis groups (Test, Peptone and Viability) and their corresponding Colony Forming Units. The results were statistically analyzed by calculating the linear regression using the minimum squares method and curves whose linear correlation $\left(\mathrm{R}^{2}\right)$ was at least 0.95 (USP, 2007) were considered satisfactory.

The robustness parameter was evaluated through the application of small changes to the microbiological method conditions. This was performed by using casein soy agar and Sabouraud dextrose agar media from three 
different laboratories (Difco ${ }^{\circledR}$, Merck $^{\circledR}$ and Oxoid ${ }^{\circledR}$ ) and incubating at different temperatures for yeast and most $\left(22 \pm 2{ }^{\circ} \mathrm{C}\right.$ and $\left.30 \pm 2{ }^{\circ} \mathrm{C}\right)$ and bacteria $\left(30 \pm 2{ }^{\circ} \mathrm{C}\right.$ and $35 \pm 2{ }^{\circ} \mathrm{C}$ ) and by varying sodium polysorbate 80 neutralizing concentration from $0.4 \%$ to $3 \%$ in casein soy broth. These tests were performed in triplicate and the results were evaluated by analysis of variance (ANOVA) (Neto, Scarmino, Bruns, 2001).

\section{Microbial count of medicine}

After validation of the medicine's microbial counting method and after preservative neutralization, a count of bacteria and most that would possibly grow under aerobic conditions was performed. This was done by incorporating $10.0 \mathrm{~mL}$ of mebendazole oral suspension in $90.0 \mathrm{~mL}$ soybean casein broth with the addition of neutralizing agents $0.4 \%$ sodium polysorbate $80(\mathrm{w} / \mathrm{v})$ and $0.5 \%$ soy lecithin $(\mathrm{w} / \mathrm{v})(1: 10) .1 .0 \mathrm{~mL}$ aliquots of this preparation were placed in Petri dishes and then $17 \pm 2.0 \mathrm{~mL}$ of casein soy agar or Sabouraud dextrose agar solid media was poured. The plates were homogenized, their contents solidified and then incubated at $32 \pm 2{ }^{\circ} \mathrm{C}$ for 48 hours for bacteria and $22 \pm 2{ }^{\circ} \mathrm{C}$ for 48 hours to 96 hours for yeasts and most. After this period colony counting was performed using a digital counter (Quimis ${ }^{\circledR}$ ) and results expressed in CFU $/ \mathrm{mL}$.

\section{Evaluation of microbial growth and sterility of culture media}

Liquid and solid casein soy media and Sabourauddextrose solid medium were used to evaluate test micro- organisms' growth. These media were inoculated with $10^{2} \mathrm{CFU} / \mathrm{mL}$ and incubated at $32 \pm 2{ }^{\circ} \mathrm{C}$ for 48 hours for bacteria and $22 \pm 2{ }^{\circ} \mathrm{C}$ for 48 hours for yeasts and 96 for most. Parallel to this assessment, media sterility and purity of microbial cultures were observed.

\section{RESULTS AND DISCUSSION}

\section{Validation of preservative neutralization}

Neutralization effectiveness was observed by the high recovery percentage in the test group which ranged from $90.95 \%$ to $99.72 \%$ for mebendazole oral suspension $20 \mathrm{mg} / \mathrm{mL}$. Along with recovery determination, the nontoxicity of neutralizers was confirmed by the recovery rates of microorganisms in the peptone group which ranged from $93.53 \%$ to $103.82 \%$ (Table I).

During the validation process of microbiological methods, microorganism variability should be taken into account (USP, 2007). Three sources of variation are commonly present: the distribution error of samples, the cellular morphology and metabolic activity of microorganisms. It is known that microorganism distribution occurs heterogeneously. During laboratory tests, it must be assumed that the product was produced under homogeneous conditions because only then is it possible to extrapolate results (PDA, 2000). From values obtained, analysis groups showed percentage values of test microorganism recovery to lie within pharmacopoeial standards, showing a homogeneous distribution of these cells with $95 \%$ confidence of accuracy, whereas Student's t test revealed no difference for the values obtained between test and peptone

TABLE I - Neutralization Evaluation of preservative for Mebendazole Oral Suspension $20 \mathrm{mg} / \mathrm{mL}$ by LAFEPE ${ }^{\circledR}$ with three analysis groups: viability $(\mathrm{V})$, peptone $(\mathrm{P})$ and test $(\mathrm{T})$, and respective values for $\mathrm{t}_{\text {tabulated }}$ and $\mathrm{t}_{\text {calculated }}$ with $95 \%$ accuracy

\begin{tabular}{|c|c|c|c|c|c|c|c|c|c|c|}
\hline \multirow{2}{*}{ Microorganisms } & \multirow{2}{*}{ UFC/plate } & \multicolumn{9}{|c|}{ Analysis Groups } \\
\hline & & $\mathbf{V}(\mathrm{X})$ & $\mathbf{T}(\mathbf{X})$ & $\% \mathbf{R}$ & $\mathbf{t}_{\mathrm{tab}}$ & $\mathbf{t}_{\text {calc }}$ & $\mathbf{P}(\mathbf{X})$ & $\% \mathbf{R}$ & $\mathbf{t}_{\text {tab }}$ & $\mathbf{t}_{\text {calc }}$ \\
\hline \multirow{2}{*}{$\begin{array}{l}\text { Aspergillus niger } \\
\text { ATCC } 16404\end{array}$} & $10-30$ & 19.00 & 17.40 & 93.55 & \multirow{10}{*}{2.77} & 2.35 & 18.60 & 97.89 & \multirow{10}{*}{2.77} & 2.44 \\
\hline & $30-300$ & 72.20 & 71.00 & 99.72 & & 1.41 & 71.20 & 98.61 & & 0.13 \\
\hline \multirow{2}{*}{$\begin{array}{l}\text { Candida albicans } \\
\text { ATCC } 10231\end{array}$} & $10-30$ & 43.0 & 37.80 & 92.64 & & 2.52 & 40.80 & 94.00 & & 2.02 \\
\hline & $30-300$ & 125.60 & 123.20 & 99.52 & & 0.79 & 123.80 & 98.57 & & 0.26 \\
\hline \multirow{2}{*}{$\begin{array}{l}\text { Escherichia coli } \\
\text { ATCC } 8739\end{array}$} & $10-30$ & 48.00 & 46.00 & 98.71 & & 0.64 & 46.60 & 97.08 & & 0.36 \\
\hline & $30-300$ & 152.80 & 149.00 & 97.13 & & 0.36 & 153.40 & 100.39 & & 0.95 \\
\hline \multirow{2}{*}{$\begin{array}{l}\text { Pseudomonas aeruginosa } \\
\text { ATCC } 9027\end{array}$} & $10-30$ & 19.00 & 18.20 & 96.81 & & 0.66 & 18.80 & 98.94 & & 1.17 \\
\hline & $30-300$ & 99.20 & 96.20 & 97.96 & & 1.75 & 98.20 & 98.99 & & 0.91 \\
\hline \multirow{2}{*}{$\begin{array}{l}\text { Staphylococcus aureus } \\
\text { ATCC } 6538\end{array}$} & $10-30$ & 40.20 & 34.20 & 90.95 & & 1.17 & 37.60 & 93.53 & & 1.49 \\
\hline & $30-300$ & 130.80 & 130.40 & 96.02 & & 1.63 & 135.80 & 103.82 & & 1.36 \\
\hline
\end{tabular}

$\mathrm{CFU}=$ Colony Forming Units, $\mathrm{X}=$ quintuplicate average, $\% \mathrm{R}=$ recovery percentage 
groups, as well as between peptone and viability groups.

Cell morphology is also a point that warrants consideration (USP, 2007). Microorganisms exhibit a variety of morphologies during their formation in colonies that may occur singly or in pairs, tetrads or irregular clusters. Some microorganisms have the ability to form biofilms, which will also affect results. The number of colony forming units formed by plates directly affects the colony morphology and precision of cell counts (PDA, 2000). The USP 30 states that recovery of test microorganisms must be greater than or equal to $70 \%$. Thus, it can be observed that results are in accordance with pharmacopoeial standards.

The nature of contaminant microorganisms and microbiological variability exert a strong effect on the response to the antimicrobial agent and the neutralization required in recovery (USP, 2007). The validation process of neutralization of antimicrobial agents showed adequate recovery of bacteria, most and yeasts with maximum incrimination values of $10^{2} \mathrm{CFU} / \mathrm{mL}$, confirming that these microorganisms were not inhibited by the test sample, mebendazole, or by the neutralization system consisting of $0.4 \%$ polysorbate 80 and $0.5 \%$ soy lecithin (Kampf, Shaffer, Hunte, 2005; Kratzer et al., 2006). As shown, the efficacy and toxicity of the neutralizer was confirmed by the recovery rates greater than $70 \%$ in the test and peptone groups, respectively, thereby assuring the efficiency of method.

\section{Development and validation of microbial counting method}

The microbial counting method proved accurate on both parameters. Accuracy is defined by USP 30 as the degree of data approximation obtained in the analysis. Precision is usually expressed by relative standard deviation (RSD) or coefficient of variation (CV\%). In the repeatability parameter, the three analysis groups inoculated with two different microorganism concentrations (10-30 CFU/ plate and 30-300 CFU/plate) had lower coefficients of variation than those recommended by USP (Table II). This compendium allows for up to $25 \%$ variation in microbial recovery for inoculations of test organisms at 10-30 CFU/plate and 15\% for the range of 30-300 CFU/ plate. For intermediate precision (Table III), no statistically significant differences were evident between the results of microorganism recovery done by two different analysts. The $\mathrm{F}$ values calculated were lower than the tabulated $\mathrm{F}$ values, confirming with $95 \%$ confidence that the method is accurate.

The accuracy of the method was demonstrated through two levels of incrimination, 10-30 CFU/plate and 30-300 CFU/plate. The test accuracy was attained by comparing the CFU/plate of the test and peptone groups with the viability group (control group). There was no significant difference in the recovery of test microorganisms between peptone and test groups when compared to viability $(p \leq 0.05)$. The recovery percentages for the two levels of microbial incrimination were greater than $70 \%$ (Table IV). These data are consistent with the limits set forth by the USP 30, establishing that the microbiological recovery must be less than $70 \%$. The method was therefore accurate, as confirmed by Student's t test, since no significant differences were found between obtained $(\mathrm{t}$ cal $)$ and expected $(\mathrm{t} t \mathrm{tab})$ values $(\mathrm{p} \leq 0.05)$.

TABLE II - Repeatability values obtained of microbial counting method for mebendazole oral suspension $20 \mathrm{mg} / \mathrm{mL}$ LAFEPE $^{\circledR}$ with two levels of incrimination among three analysis groups: viability $(\mathrm{V})$, peptone $(\mathrm{P})$ and test $(\mathrm{T})$

\begin{tabular}{lcccc}
\hline Microorganisms & Levels of Incrimination & \multicolumn{3}{c}{ Analysis groups (CV\%) } \\
\cline { 2 - 5 } & CFU/plate & $\mathrm{V}$ & $\mathrm{P}$ & $\mathrm{T}$ \\
\hline Aspergillus niger ATCC & $10-30$ & 14.89 & 14.43 & 15.02 \\
Candida albicans ATCC & $30-300$ & 9.76 & 11.56 & 9.50 \\
& $10-30$ & 16.66 & 13.80 & 6.59 \\
Escherichia coli ATCC & $30-300$ & 1.83 & 6.99 & 2.88 \\
& $10-30$ & 10.10 & 15.52 & 9.22 \\
Pseudomonas aeruginosa ATCC & $30-300$ & 3.96 & 2.24 & 5.69 \\
& $10-30$ & 13.99 & 15.25 & 11.53 \\
Staphylococcus aureus ATCC & $30-300$ & 6.55 & 5.26 & 2.80 \\
& $10-30$ & 14.88 & 4.34 & 21.36 \\
& $30-300$ & 2.72 & 4.37 & 4.49 \\
\hline
\end{tabular}

$\mathrm{CFU}=$ Colony Forming Units, CV\%=Coefficient of Variation 
TABLE III - Values obtained on Determination of Intermediate Precision of microbial counting method done by two different analysts for Mebendazole Oral Suspension $20 \mathrm{mg} / \mathrm{mL}$ LAFEPE ${ }^{\circledR}$ with two levels of incrimination among three analysis groups: viability $(\mathrm{V})$, peptone $(\mathrm{P})$ and test $(\mathrm{T})$ and respective values for $\mathrm{F}_{\text {tabulated }}$ and $\mathrm{F}_{\text {calculated }}$ with $95 \%$ accuracy

\begin{tabular}{|c|c|c|c|c|c|c|c|c|c|c|c|}
\hline \multirow{3}{*}{ Microorganisms } & \multirow{3}{*}{ Analyst } & \multicolumn{10}{|c|}{ Levels of Incrimination } \\
\hline & & \multicolumn{5}{|c|}{10 - $30 \mathrm{CFU} /$ plate $(\mathrm{X} \pm \mathrm{SD})$} & \multicolumn{5}{|c|}{$30-300 \mathrm{CFU} /$ plate $(\mathrm{X} \pm \mathrm{SD})$} \\
\hline & & $\mathrm{V}$ & $\mathrm{P}$ & $\mathrm{T}$ & $\mathrm{F}_{\text {tab }}$ & $\mathrm{F}_{\text {cal }}$ & $\mathrm{V}$ & $\mathrm{P}$ & $\mathrm{T}$ & $\mathrm{F}^{*}{ }_{\text {tab }}$ & $\mathrm{F}_{\text {cal }}$ \\
\hline ATCC 16404 & 2 & $19.00 \pm 2.83$ & $17.40 \pm 2.51$ & $18.60 \pm 2.79$ & & 0.78 & $72.20 \pm 7.50$ & $71.20 \pm 8.23$ & $71.00 \pm 6.75$ & & 2.43 \\
\hline Candida albicans ATCC & 1 & $33.40 \pm 7.23$ & $25.00 \pm 4.66$ & $38.40 \pm 5.22$ & & 1.71 & $131.20 \pm 7.19$ & $128.00 \pm 6.71$ & $128.40 \pm 9.40$ & & 1.01 \\
\hline ATCC 8739 & 2 & $48.00 \pm 4.85$ & $46.60 \pm 7.23$ & $46.00 \pm 4.24$ & 2.62 & 1.86 & $152.80 \pm 6.06$ & $153.40 \pm 3.44$ & $149.00 \pm 8.49$ & 2.62 & 2.02 \\
\hline Pseudomonas & 1 & $19.60 \pm 4.39$ & $20.40 \pm 3.51$ & $16.20 \pm 1.79$ & & \multirow{2}{*}{1.21} & $89.60 \pm 13.16$ & $97.00 \pm 3.67$ & $96.20 \pm 3.11$ & & \multirow{2}{*}{0.84} \\
\hline aeruginosa ATCC 9027 & 2 & $17.80 \pm 2.49$ & $18.20 \pm 2.77$ & $18.80 \pm 2.17$ & & & $96.20 \pm 6.30$ & $98.20 \pm 5.17$ & $99.20 \pm 2.77$ & & \\
\hline Staphylococcus aureus & 1 & $37.20 \pm 4.87$ & $36.40 \pm 3.58$ & $45.40 \pm 9.48$ & & 1.95 & $138.20 \pm 6.61$ & $138.80 \pm 6.76$ & $137.40 \pm 7.89$ & & 1.78 \\
\hline
\end{tabular}

$\mathrm{CFU}=$ Colony Forming Units; $\mathrm{X}=$ quintuplicate average, $\mathrm{SD}=$ standard deviation

TABLE IV - Values obtained for Accuracy of microbial counting method for Mebendazole Oral Suspension $20 \mathrm{mg} / \mathrm{mL}$ LAFEPE $^{\circledR}$ with two levels of incrimination among three analysis groups: viability $(\mathrm{V})$, peptone $(\mathrm{P})$ and test $(\mathrm{T})$, and respective values for $t_{\text {tabulated }}$ and $t_{\text {calculated }}$ with $95 \%$ accuracy

\begin{tabular}{|c|c|c|c|c|c|c|c|}
\hline \multirow{3}{*}{ Microorganisms } & & \multicolumn{6}{|c|}{ Levels of Incrimination } \\
\hline & & \multicolumn{3}{|c|}{10 - $30 \mathrm{CFU} /$ plate } & \multicolumn{3}{|c|}{$30-300 \mathrm{CFU} /$ plate } \\
\hline & & $\% \mathrm{R}$ & $\mathrm{t}_{\mathrm{tab}}$ & $\mathrm{t}_{\mathrm{cal}}$ & $\% \mathrm{R}$ & $\mathrm{t}_{\mathrm{tab}}$ & $\mathrm{t}_{\mathrm{cal}}$ \\
\hline \multirow[t]{3}{*}{ Aspergillus niger ATCC 16404} & $\mathrm{~V}$ & 100.00 & & & 100.00 & & \\
\hline & $\mathrm{P}$ & 91.58 & & 2.35 & 98.61 & & 1.41 \\
\hline & $\mathrm{T}$ & 97.89 & & 1.63 & 98.34 & & 1.17 \\
\hline \multirow[t]{3}{*}{ Candida albicans ATCC 10231} & $\mathrm{~V}$ & 100.00 & & & 100.00 & & \\
\hline & $\mathrm{P}$ & 94.01 & & 2.52 & 98.09 & & 0.79 \\
\hline & $\mathrm{T}$ & 87.10 & & 2.48 & 98.57 & & 1.72 \\
\hline \multirow[t]{3}{*}{ Escherichia coli ATCC 8739} & $\mathrm{~V}$ & 100.00 & & & 100.00 & & \\
\hline & $\mathrm{P}$ & 98.11 & 2.77 & 0.64 & 100.39 & 2.77 & 0.36 \\
\hline & $\mathrm{T}$ & 83.71 & & 1.36 & 97.51 & & 0.63 \\
\hline \multirow[t]{3}{*}{ Pseudomonas aeruginosa ATCC 9027} & $\mathrm{~V}$ & 100.00 & & & 100.00 & & \\
\hline & $\mathrm{P}$ & 102.25 & & 0.66 & 102.08 & & 1.75 \\
\hline & $\mathrm{T}$ & 105.62 & & 1.11 & 103.12 & & 1.76 \\
\hline \multirow[t]{3}{*}{ Staphylococcus aureus ATCC 6538} & $\mathrm{~V}$ & 100.00 & & & 100.00 & & \\
\hline & $\mathrm{P}$ & 90.96 & & 1.17 & 103.82 & & 1.63 \\
\hline & $\mathrm{T}$ & 106.91 & & 1.51 & 99.69 & & 0.30 \\
\hline
\end{tabular}

$\mathrm{CFU}=$ Colony Forming Units, $\% \mathrm{R}=$ percentage recovery on comparison of test microorganisms

The microbial count is influenced by metabolic activity, genotype and microorganism distribution for growth. During the analysis, microorganisms may be stressed due to environmental conditions or inhibitory components of the formulation itself, thus reducing the method accuracy. It may be noted that peptone recovery values of over $100 \%$ were found, where this may be due to microbial variability. Regarding the values over $100 \%$ in the test group, these 
TABLE V - Linearity values obtained of microbial counting method for Mebendazole Oral Suspension $20 \mathrm{mg} / \mathrm{mL} \mathrm{LAFEPE}^{\circledR}$ among the analysis groups: viability $(\mathrm{V})$, peptone $(\mathrm{P})$ and test $(\mathrm{T})$, and respective values for $\mathrm{F}_{\text {tabulated }}$ and $\mathrm{F}_{\text {calculated }}$ with $95 \%$ accuracy

\begin{tabular}{|c|c|c|c|c|c|}
\hline Microorganisms & & Linear Coefficient \pm SD & $\mathrm{R}^{2}$ & $\mathrm{~F}_{\mathrm{tab}}$ & $\mathrm{F}_{\text {cal }}$ \\
\hline \multirow[t]{3}{*}{ Aspergillus niger ATCC 16404} & $\mathrm{~V}$ & $87.85 \pm 0.49$ & 0.9872 & & 0.87 \\
\hline & $\mathrm{P}$ & $73.66 \pm 2.00$ & 0.9784 & & \\
\hline & $\mathrm{T}$ & $128.57 \pm 4.64$ & 0.9854 & & \\
\hline \multirow[t]{3}{*}{ Candida albicans ATCC 10231} & $\mathrm{~V}$ & $109.47 \pm 3.03$ & 0.9694 & & 2.23 \\
\hline & $\mathrm{P}$ & $102.57 \pm 5.82$ & 0.9846 & & \\
\hline & $\mathrm{T}$ & $116.62 \pm 2.76$ & 0.9932 & & \\
\hline \multirow[t]{3}{*}{ Escherichia coli ATCC 8739} & $\mathrm{~V}$ & $77.53 \pm 9.83$ & 0.9799 & & 0.10 \\
\hline & $\mathrm{P}$ & $102.52 \pm 8.83$ & 0.9766 & 5.14 & \\
\hline & $\mathrm{T}$ & $90.76 \pm 4.28$ & 0.9806 & & \\
\hline \multirow[t]{3}{*}{ Pseudomonas aeruginosa ATCC 9027} & $\mathrm{~V}$ & $30.94 \pm 2.30$ & 0.9788 & & 0.21 \\
\hline & $\mathrm{P}$ & $43.52 \pm 7.03$ & 0.9710 & & \\
\hline & $\mathrm{T}$ & $51.38 \pm 4.65$ & 0.9544 & & \\
\hline \multirow[t]{3}{*}{ Staphylococcus aureus ATCC 6538} & $\mathrm{~V}$ & $34.79 \pm 3.18$ & 0.9773 & & 0.55 \\
\hline & $\mathrm{P}$ & $39.04 \pm 2.50$ & 0.9759 & & \\
\hline & $\mathrm{T}$ & $45.38 \pm 3.38$ & 0.9853 & & \\
\hline
\end{tabular}

$\mathrm{SD}=$ standard deviation, $\mathrm{R}^{2}=$ correlation coefficient

may be due to the use of neutralizing agents that can inactivate some products that cause stress to cells. Similarly, the mebendazole may contain sufficient nutrients to ensure the survival of microorganisms or maintenance of their growth rates.

The method's linearity was demonstrated by the proportional relationship between the number of colony forming units detected in the three analysis groups and their volumes taken $(0.2,0.4,0.6,0.8,1.0$ and $1.2 \mathrm{~mL})$. The values of correlation coefficients $\left(\mathrm{R}^{2}\right)$ ranged from 0.9694 to 0.9932 for the oral suspension of mebendazole (Table $\mathrm{V})$. These values are consistent with values established by the USP 30 , which determines $\mathrm{R}^{2}>0.95$. No statistically significant correlation of the linear coefficients obtained for the three analysis groups was found $(\mathrm{p} \leq 0.05)$.

A method is considered robust when it has the ability to provide unchanged results even when subjected to changes. Robustness is the parameter that most closely matches the laboratory reality since it evaluates the results under different conditions of analysis showing the values that can be acceptable in the face of changing conditions of analysis.

Given the change of parameters such as temperature, concentration of sodium polysorbate 80 and culture media, the results of microbial counts were not statistically different from those obtained under conditions defined as standard $(\mathrm{p} \leq 0.05)$ (Table VI).

\section{Microbial count of medicine}

The microbial count test was performed for Mebendazole oral suspension $20 \mathrm{mg} / \mathrm{mL}$ - LAFEPE $^{\circledR}$ and no viable cells were recovered.

\section{Test of microbial growth promotion and sterility of culture media}

The culture media used in this experiment proved its ability to promote microbial growth under the test conditions. The sterility test showed absence of viable microorganisms.

\section{CONCLUSION}

In the routine microbiological analyses of drugs, analytical methods should be validated to allow reliable 
TABLE VI - Values obtained on Robustness Determination of methodology for Mebendazole Oral Suspension 20mg/ml LAFEPE ${ }^{\circledR}$, based on average CFU from triplicates with variation in temperature, polysorbate 80 and culture media, and respective values for $\mathrm{F}_{\text {tabulated }}$ and $\mathrm{F}_{\text {calculated }}$ with $95 \%$ accuracy

\begin{tabular}{|c|c|c|c|c|c|}
\hline \multirow{2}{*}{ Parameters } & \multicolumn{5}{|c|}{ Microorganisms 30 - $300 \mathrm{CFU} /$ plate } \\
\hline & $\mathrm{AN}(\mathrm{X} \pm \mathrm{SD})$ & $\mathrm{CA}(\mathrm{X} \pm \mathrm{SD})$ & $\mathrm{EC}(\mathrm{X} \pm \mathrm{SD})$ & $\mathrm{PA}(\mathrm{X} \pm \mathrm{SD})$ & $\mathrm{SA}(\mathrm{X} \pm \mathrm{SD})$ \\
\hline \multicolumn{6}{|c|}{ Temperature $\left({ }^{\circ} \mathrm{C}\right)$} \\
\hline $22 \pm 2$ & $129.33 \pm 2.84$ & $120.88 \pm 2.52$ & NA & NA & NA \\
\hline $30 \pm 2$ & $119.77 \pm 0.50$ & $122.33 \pm 5.50$ & $72.22 \pm 3.28$ & $43.11 \pm 5.16$ & $31.66 \pm 4.72$ \\
\hline $35 \pm 2$ & NA & NA & $69.88 \pm 2.77$ & $44.00 \pm 9.86$ & $34.44 \pm 4.22$ \\
\hline $\mathrm{F}_{\mathrm{tab}}$ & 3.10 & & & & \\
\hline $\mathrm{F}_{\text {cal }}$ & 1.67 & 0.55 & 0.91 & 1.66 & 2.74 \\
\hline \multicolumn{6}{|l|}{ Polysorbate 80} \\
\hline $0.4 \%(\mathrm{p} / \mathrm{v})$ & $75.33 \pm 1.17$ & $126.13 \pm 5.52$ & $82.40 \pm 3.90$ & $232.26 \pm 13.32$ & $38.73 \pm 3.05$ \\
\hline $3.0 \%(\mathrm{p} / \mathrm{v})$ & $72.26 \pm 4.74$ & $130.73 \pm 2.71$ & $82.26 \pm 1.52$ & $239.73 \pm 16.02$ & $38.53 \pm 4.27$ \\
\hline $\mathrm{F}_{\text {tab }}$ & 2.62 & & & & \\
\hline $\mathrm{F}_{\text {cal }}$ & 1.39 & 0.65 & 0.50 & 0.29 & 2.31 \\
\hline \multirow{2}{*}{\multicolumn{6}{|c|}{$\begin{array}{l}\text { Culture medium } \\
\text { (TSA or SDA) }\end{array}$}} \\
\hline & & & & & \\
\hline Merck & $142.78 \pm 3.56$ & $123.33 \pm 2.67$ & $69.89 \pm 2.78$ & $39.22 \pm 2.71$ & $31.78 \pm 3.47$ \\
\hline Difco & $138.44 \pm 13.04$ & $122.22 \pm 1.84$ & $77.11 \pm 10.33$ & $38.33 \pm 4.37$ & $33.56 \pm 1.64$ \\
\hline Oxoid & $129.33 \pm 2.85$ & $123.33 \pm 5.51$ & $83.56 \pm 2.78$ & $44.00 \pm 9.87$ & $34.44 \pm 4.22$ \\
\hline $\mathrm{F}_{\mathrm{tab}}$ & 2.51 & & & & \\
\hline $\mathrm{F}_{\mathrm{cal}}$ & 1.06 & 0.40 & 2.41 & 2.28 & 1.40 \\
\hline
\end{tabular}

$\mathrm{CFU}=$ Colony Forming Units; $\mathrm{AN}=$ Aspergillus niger $\mathrm{ATCC} 16$ 404, $\mathrm{CA}=$ Candida albicans $\mathrm{ATCC} 10231, \mathrm{EC}=$ Escherichia coli ATCC 8739, PA = Pseudomonas aeruginosa ATCC 9027; SA = Staphylococcus aureus ATCC 6538; NA = not assessed; X = triplicate average, $\mathrm{SD}=$ standard deviation; $\mathrm{TSA}=$ casein soy agar, $\mathrm{SDA}=$ Sabouraud dextrose agar

results which can be interpreted satisfactorily given the wide variability of microorganisms involved in microbial analysis.

The aim of this study was to validate the microbial counting method in mebendazole oral suspension. The method was in accordance with the Good Laboratory Practice, and proved to be accurate, robust while exhibiting good linearity. Thus, the method was in accordance with official standards established for the validation of microbiological methods and for providing reproducibility within the pharmaceutical industry.

\section{REFERENCES}

AGATONOVIC-KUSTRIN, A., GLASS, B. D., MANGAN, M., SMITHSON, J. Analysing the crystal purity of mebendazole raw material and its stability in a suspension formulation. Int. J. Pharm., v.361, n.1-2, p. 245-250, 2008.
BENETT, A., GUYATT, H. Reducing Intestinal Nematode Infection: Efficacy of Albendazole and Mebendazole. Parasitol. Today, v.16, n.2, p.71-74, 2000.

BOMBLIES, L., WEISS, C., BECKMANN, G. Examination of microbiological quality of pharmaceutical raw materials. Pharm. Eur. Sci. Notes, v.1, n.1, p.1-7, 2007.

BOU-CHACRA, N. A., OHARA, M. T. Validação de método para avaliação da qualidade sanitária de preparação cosmética de base lipófila. Rev. Bras. Cienc. Farm., v.39, n.2, p.185-194, 2003.

CARVALHO, A., MEURER, V., PINTO, T., YAMAMOTO, C. Controle de qualidade microbiológica de produtos farmacêuticos, cosméticos e fitoterápicos produzidos na Zona da Mata. In: CONGRESSO BRASILEIRO DE EXTENSÃO UNIVERSITÁRIA, 2., Belo Horizonte, 2004. Anais. Belo Horizonte: UFMG, 2004. p.42-47. 
FARMACOPÉIA BRASILEIRA. 4. ed. São Paulo: Atheneu, 1988. p.V.5.1.6.

GOODMAN, A. G., HARDMAN, J. G., LIMBIRD, L. E., MOLINOFF, P. B., RUDDON, R.W. Goodman \& Gilman As bases farmacológicas da terapêutica. 11. ed. Rio de Janeiro: McGraw-Hill Interamericana do Brasil, 2006. p.254.

ITAH, A.Y., UDOKPOH, A.E., OFUM, M.U. Bacteriological quality of some pharmaceutical products marketed by drugs vendors in uyo, Nigeria. Afr. J. Health Sci.,v.11, n.3-4, p.128-133, 2004.

KAMPF, G., SHAFFER, M., HUNTE, C. Insufficient neutralization in testing a chlorhexidine containing ethanolbased hand rub can result in a false positive efficacy assessment. BMC Infect. Dis. v.5, n.48, p.1-5, 2005.

KRATZER, C., TOBUDIC, S., ASSADIAN, O., BUXBAUM, A., GRANINGER, W., GEORGOPOULOS, A. Validation of akacid plus as a room disinfectant in the hospital setting. Appl. Environ. Microbiol., v.72, n.6, p.3826-3831, 2006.

NETO, B. B., SCARMINO, I. S., BRUNS, R. E. Como fazer experimentos: pesquisa e desenvolvimento na ciência e na indústria. São Paulo: Editora da Unicamp, 2001. p.9-82, 201-248.
PARENTERAL DRUG ASSOCIATION. Technical Report n. 33. Evaluation, validation and implementation of new microbiological testing methods. J. Pharm. Sci. Tech., v.54, n.3, p.1-38, 2000.

PINTO, T. J. A., KANEKO, T. M., OHARA, M. T. Controle biológico de qualidade de produtos farmacêuticos, correlatos e cosméticos. 2.ed. São Paulo: Atheneu, 2003. p.219-258.

RUSSELL, A.D. Challenge testing: principles and practice. Int J. Cosmet. Sci., v.25, n.3, p.147-153, 2003.

RAMOS, S. V. V. Validação da metodologia analítica aplicada ao controle microbiológico de formas farmacêuticas líquidas e determinação da eficácia de conservantes. Recife, 2010. 164 p. [Tese de Doutorado. Departamento de Ciências Farmacêuticas. Centro de Ciências da Saúde. Universidade Federal de Pernambuco].

UNITED STATES PHARMACOPEIA. 30.ed. Rockville: The United States Pharmacopeia Convention, 2007. p.677-680; 684-686.

Received for publication on $4^{\text {th }}$ November 2010 Accepted for publication on $21^{\text {st }}$ March 2011 
